【U Home Science Extension And Communication Management

Volume 2 | Issue 2 | July, 2015 | 116-125
- DOI : 10.15740/HAS/IJHSECM/2.2/116-125

- Visit us : www.researchjournal.co.in

$\mathbf{A}^{\mathrm{Ca}} \mathbf{S}_{\mathrm{TUdy}}^{\mathrm{E}}$

\title{
Motives for volunteering : A study of Nehru Yuva Kendra Sangathan (NYKS) volunteers
}

\author{
RAINA AGGARWAL* AND ARCHNA KUMAR \\ Department of Development Communication and Extension, Lady Irwin College, Delhi University, \\ DELHI, INDIA (Email : raina_agg@yahoo.com)
}

\begin{abstract}
Why do significant numbers of people engage in the unpaid helping activities known as volunteerism? Drawing on motivations underlying human behaviour, Volunteer Function Inventory (VFI) was used. The study assess the motivational functions of youth volunteers especially decisions about becoming a volunteer in the Nehru Yuva Kendra Sangathan. Volunteerism is considered an important, and increasingly popular, mechanism for enabling young people to not only engage in social issues and contribute to sustainable human development but also their own selfdevelopment. The Nehru Yuva Kendra Sangathan (NYKS), an autonomous organization under the government is the largest network of rural youth in the country for channelizing the power of youth on the principles of voluntarism, selfhelp and community participation. The motivational profile of youth volunteers captured by Volunteer Function Inventory revealed that 'understanding' was the most important function of motivation i.e. volunteering in NYKS for youth volunteers was a way to gain knowledge about oneself and world, learn new skills and abilities. Understanding the differentials in volunteer function for gender, age, educational level and family income of youth further highlighted the context of the lives of youth. No difference was seen in the motivation across gender and family income. Interestingly no difference in 'career' function across all age groups further highlighted the concern of livelihood issues dominating the lives of youth volunteering with NYKS. Further, difference amongst volunteers of different educational level for 'understanding' function highlighted the difference in learning they sought due to their volunteering.
\end{abstract}

KeY WoRdS : NYKS : Nehru Yuva Kendra Sangathan, Volunteers

View Point Article : Aggarwal, Raina and Kumar, Archna (2015). Motives for volunteering : A study of Nehru Yuva Kendra Sangathan (NYKS) volunteers. Internat. J. Home Sci. Extn. \& Comm. Manage., 2 (2): 116-125.

Article History : Received : 22.05.2015; Accepted : 24.06.2015

\footnotetext{
* Author for correspondence
} 